Interactive comment on "Diverging responses of high-latitude $\mathrm{CO}_{2}$ and $\mathrm{CH}_{4}$ emissions in idealized climate change scenarios" by Philipp de Vrese et al.

Philipp de Vrese et al.

philipp.de-vrese@mpimet.mpg.de

Received and published: 25 September 2020 


\section{Response to comments of reviewer 2}

Interactive

comment

September 25, 2020

Please note that, in the following point by point address, we repeat the reviewer's comments in red letters while our response is given in black letters.

\section{General}

de Vrese and coauthors present modeling study that investigates the response of the continental high latitude carbon cycle under "idealized" transient climate change with trend inversion at different points in time during the course of this century. The paper is in general very clear and addresses the important question of how the carbon cycle reacts under overshoot scenarios. It provides interesting into the complex interplay between the numerous processes and factors that would determine the trajectory of the climate system under overshoot scenarios, although it is clear that the current uncertainties (appropriately acknowledged in the paper) preclude firm predictions of he evolution of continental high latitude $\mathrm{CO} 2$ and $\mathrm{CH} 4$ fluxes under such scenarios. The paper is well structured and also well written, although, as far as I can judge(I'm not a native speaker either), the English could be improved in many places (for example: 1 
- there are many commas that would be in place in German but not in English; 2 - the possessive case is often wrongly used [" 's " should be used only for person, not for things as far as I know]; 3 - hyphenation is probably used too often between two nouns, just to give a few examples of what I think are repeated errors).I have some comments and suggestions that I hope might be useful to clarify some aspects of the paper.

Interactive

comment

\section{Comments}

- L. 52-54: Clarify that large-scale models actually represent the thaw depth and do not represent processes like thaw settling and thermokarst, which occur faster ("abrupt"); these are indeed local processes but why should their occurrence by widespread?

In hindsight, this sentence may have been misleading. By stating that the processes are locally confined we did not want to indicate whether or not they are widespread but merely that they are not captured by large-scale models - which makes it difficult to estimate how Arctic GHG-emissions will develop in the future. We hope to clarify this by changing the sentence to: "While local observations indicate that the change processes, affecting the soil carbon emissions, are often locally confined and act on very short timescales, large-scale models do not represent these small-scale processes. Thus, studies relying on these models suggest that the increase in emissions is likely to occur gradually over a timescale of hundreds of years (Schuur, 2015)".

- L.72-76: Indeed there isn't much literature focusing on the behaviour of the Arctic continental ecosystems under overshoot scenarios. But there are several global studies, I think, from which information about the Arctic might be extracted. Maybe also check what the IPCC SROCC and SR1.5 say?

Printer-friendly version

It is correct that there is a number of studies that look at overshoot scenarios 
on the global scale, including permafrost regions. However, - to the best of our knowledge - the models used for these studies predominantly lack the representation of relevant processes. Here, the MPI-ESM is an excellent example: The standard model does not include the organic matter stored in the perennially frozen parts of the ground and thus, misses the carbon release due to permafrost degradation. It also does not represent freezing and thawing of soil water and misjudges the timescale of the hysteresis. Thus, the issue with the focus is not only a question of spatial scales but also of model capabilities.

- L.117: Hard to understand what is done here with r_cin. Maybe a schematic could help?

Here we tried to clarify the use of $r_{\text {_cin }}$ by providing the respective equations: "The present model version distinguishes between anoxic and oxic decomposition in the inundated and the non-inundated fractions of the grid box (see below) and the soil carbon pools need to be separated accordingly. Here, we do not simulate the respective pools explicitly. Instead we calculate $r_{C_{i n}}^{t_{\text {end }}}$, the ratio between the carbon concentrations in the inundated $\left(C_{\text {in }}^{t_{\text {end }}}\right)$ and the non-inundated $\left(C_{d r y}^{t_{\text {end }}}\right)$ fractions, for each of the soil carbon pools after the decomposition is computed in timestep $t$.

$$
r_{C_{i n}}^{t_{e n d}}=\frac{C_{i n}^{t_{e n d}}}{C_{d r y}^{t_{e n d}}}
$$

In the consecutive time step $t+1$, the soil carbon is distributed between inundated and non-inundated carbon pools according to $r_{C_{i n}}^{t_{\text {end }}}$ before the decomposition is calculated. $\quad \mathrm{C}_{\text {in }}^{t+1_{\text {start }}}=C_{\text {tot }}^{t+1_{\text {start }}}\left(1+\frac{1}{r_{C_{\text {in }}}^{t_{\text {end }}}}\right)^{-1}$, $C_{d r y}^{t+1_{\text {start }}}=C_{\text {tot }}^{t+1_{\text {start }}}-C_{\text {in }}^{t+1_{\text {start }}}$.

- L.125-129: The vertical discretization is better described later. The short description here is frustrating because one misses some detail. 
We removed the description of the two grids entirely because the simulations that are being analyzed for the present study use the same vertical grid for physics and soil carbon. Hence, it is a technical detail of the scheme that is not relevant for the present manuscript and indeed somewhat out of place here.

- L.275: parameterization of permafrost acting against drainage: please justify (e.g. by citing appropriate references)

In general, we evaluated the parametrizations based on the simulated soil moisture profiles for selected grid boxes and on the hydrographs of the larger Arctic rivers. With respect to soil moisture profiles in grid cells underlain by permafrost, we followed Swenson (2012) who modified the soil hydrology in CLM in the presence of soil ice. Similar to CLM, the MPI-ESM initially featured extremely dry soils when accounting for freezing and melting of soil water, which is in poor agreement with observations often indicating high moisture levels within the active layer and the formation of a perched highly saturated zone on top of the perennially frozen soil layers (Swenson, 2012). Furthermore, the inhibition of drainage has to be seen in the context of the MPI-ESM's soil hydrology scheme. Even the standard 5-layer scheme assumes that water moves to the bedrock border before it drains (see Fig. 1 Hagemann (2015)) and, conceptually, the lateral drainage from overlying layers is merely an additional flow pathway that facilitates the vertical transport towards the bedrock border. This pathway represents wider fissures, cracks etc. that are not explicitly represented in the model, but are assumed to be present in all grid boxes - given the coarse, standard spatial resolution of the model. Hence, the inhibition of the lateral drainage is conceptually a limit on the vertical transport. Finally, we still allow lateral drainage from any layer in the case that the underlying soil layers are fully saturated, which we did not mention in the manuscript before. We hope to clarify this by extending the paragraph to: "Additionally, the standard model version assumes lateral drainage from all soil layers located above the bedrock. This drainage component is included

Printer-friendly version

Discussion paper 
to account for vertical channels - e.g. connected pathways in coarse material, cracks or crevices - that are assumed to be present in the large, heterogeneous grid cells at the standard resolution $\left(1.9^{\circ} \times 1.9^{\circ}\right)$. These efficiently transport the water deeper underground towards the border between soil and bedrock where it runs of as base flow. However, in the presence of permafrost, we assume these vertical channels to be predominantly blocked by ice and we allow lateral drainage only at the bedrock border or from those layers below which the soil is fully water saturated - i.e. at field capacity. These limitations on lateral drainage in combination with the inhibition of percolation for large ice contents facilitate high moisture levels within the active layer and the formation of a perched highly saturated zone on top of the perennially frozen soil layers, which are typical for permafrost regions (Swenson, 2012)".

- L.365: "likely scenario" - in principle, the IPCC scenarios have no likelihood attached. Maybe sufficient to say that SSP585 is not "business as usual" (see the comment by Hausfather and Peters, Nature 2020).

Dr. Krinner is right that there are no probabilities attached to the scenarios, thus "likely" is a somewhat problematic term - though Hausfather (2020) state that RCP8.5 was introduced as an "unlikely" scenario. To avoid the connotation of probabilities we now use "plausible scenario" in the manuscript.

- L.371: Please specify which member of the historical ensemble was used (presumably the first?)

We used the 10th ensemble member for our historical and scenario simulations and a corresponding statement is now included in the methods section. Here, the 10th member was chosen because it starts from the latest point of the pi-control simulation - after 449 years. However, this was an arbitrary choice as, to the best of our knowledge, the pi-control simulation is in an equilibrium state after the spin-up phase. 
- L.455: Unclear whether the permafrost-affected area changes in time and between the pertubed physics ensemble members in terms of the analysis, or whether it is fixed. What is the impact on the results?

This is an important factor which we indeed did not discuss sufficiently in the manuscript. For the analysis, we used fixed (in time) masks that are based on the simulation-specific near-surface permafrost extent (top $3 \mathrm{~m}$ ) of the year 2000 . For each of the simulations, the variables were aggregated over this region and we analysed the resulting spatial averages/sums. The permafrost extent varies between the simulations by up to $20 \%$ - roughly between 13 million $\mathrm{km}^{2}$ and 16 million $\mathrm{km}^{2}$ - which is also noticeable in the results, e.g. the large spread in the permafrost carbon pools can partly be attributed to the differences in the permafrost area. To clarify our approach in the manuscript, we included the following paragraph following the description of the ensemble simulations: "With respect to the results presented below, it should be noted that most of the analysis is performed based on aggregated values representative of the entire northern permafrost region - more precisely the areas that exhibit perennially frozen soils within the top 3 meter of the soil column. The extent of these areas is sensitive to the parameter values used in a specific setup and varies substantially between the simulations. For the analysis we do not define a shared permafrost mask, but aggregate the values based on the simulation-specific permafrost region. Furthermore, we base the analysis on the permafrost regions at the beginning of the 21st century - roughly between 13 million $\mathrm{km}^{2}$ and 16 million $\mathrm{km}^{2}$ - and do not adjust their extent to account for the changes in the near-surface permafrost. Nonetheless, in the manuscript we simply refer to the focus region as the permafrost regions even though large fractions of the respective areas may not feature near-surface permafrost at the higher temperatures of the assumed warming scenarios."

Printer-friendly version

Discussion paper

- L.470: $\mathrm{CH} 4$ emissions small. Specify that this is also the case in terms of forcing 
in your model. Aren't these $\mathrm{CH} 4$ emissions a bit low compared to current estimates?

As the first reviewer pointed out, the estimate of $9 \mathrm{Tg} \mathrm{CH} 4 \mathrm{yr}-1$ is a slip of the pen for which we apologize. The correct simulated emissions amount to $12 \mathrm{Tg}$ $\mathrm{CH} 4 \mathrm{yr}-1$ which is in good agreement with recent estimates - e.g. the Global Methane Budget by Saunois (2020) estimates 2 - $18 \mathrm{Tg} \mathrm{CH} 4 \mathrm{yr}-1$ for high latitude wetlands, with inversion models placing the emissions at around $13 \mathrm{Tg} \mathrm{CH} 4 \mathrm{yr}-1$ and land surface models at $9 \mathrm{Tg} \mathrm{CH} 4 \mathrm{yr}-1$. In the manuscript we corrected the value (9 -> $12 \mathrm{Tg} \mathrm{CH} 4 \mathrm{yr}-1$ ), included a reference to Saunois (2020) and clarify that our study focuses on the natural emissions from to wetlands. To this end we included the following statement in the description of the methane-module:"lt should be noted that the model also simulates the $\mathrm{CH}_{4}$ emissions from wildfires and termites. However, with the focus of this study on soil emissions, we neglect these fluxes in the detailed discussion of the methane emissions and exclusively report the fluxes from wetlands and inundated areas" and clarify that "At the beginning of the 21 st century the simulated net $\mathrm{CH}_{4}$ emissions from water saturated high latitude soils amount to roughly $9 \mathrm{Mt}(\mathrm{C})$ year ${ }^{-1}$ - or about $12 \mathrm{Tg}\left(\mathrm{CH}_{4}\right)$ year $^{-1}$, which is in good agreement with recent estimates of high latitude wetland emissions (Saunois, 2020)."

- L.491: higher end of previous estimates: I have the impression that the nearsurface permafrost extent in the MPI model has a very strong sensitivity to GSAT, compared to other models. Is this correct? If yes, what is the reason? Is the Arctic amplification particularly strong in this model or does the soil react very quickly and strongly?

It is correct that in the high northern latitudes the model reacts strongly to the GSAT increase which, as Dr. Krinner correctly speculated, is in large parts due to a strong Arctic amplification. While the MPIESM1.2 has a low climate sensitivity, Arctic temperatures increase comparatively fast with rising $\mathrm{CO} 2 \mathrm{~s}$. Following 
RCP8.5/SSP5, the near surface temperatures in the continental Arctic increase by about $10 \mathrm{~K}$ (relative to 1960 ) by the year 2100 , while other models reach this threshold between 25 - 75 years later (see Fig. 2 in Andresen (2020)). How the land surface reacts to a temperature increase of $10 \mathrm{~K}$ is also largely model dependent - e.g. while CLM loses only half of the near surface permafrost (in terms of area), there is a number of models that appear to loose most of the near surface permafrost for a $10 \mathrm{~K}$ warming. Here, the below-ground temperatures in the standard JSBACH model - at least the HR version - appear to more sensitive to rising atmospheric temperatures than they are in other models (see Fig. 12 b, Burke (2020)). However, in our model version we have changed a number of important parameters - e.g. soil depth, number of soil layers, soil properties depending on organic matter - and parametrizations - e.g. water in the soil freezes and melts - which reduced this sensitivity substantially. In general, the reason why land surface models react so differently is, to the best of our knowledge, still somewhat unclear because they are very similar in many aspects of the soil physics and there doesn't appear to be a single characteristic that sets models with a strong reaction apart from those indicating a weaker response to warming.

- L.506-519: This tree fraction hysteresis is interesting and intriguing. Can you discuss this a bit more? What happens exactly? Why aren't these trees here in the first place? Is this realistic?

The hysteretic behaviour is indeed an interesting results of our simulations and we conducted an extensive analysis of the underlying mechanisms. However, a detailed explanation, including the question whether the effects of a temporary warming are fully reversible, is rather lengthy and beyond the scope of this study, especially as it requires several sets of additional simulations. Unfortunately, we had to conclude that it is best to focus on the GHG emissions and discuss the hysteresis in a separate study. However, we don't want to give the impression of avoiding Dr. Krinner's question and a simplified answer is that the hysteretic 
behaviour stems partly from the representation of the vegetation dynamics in JS$\mathrm{BACH}$, where the transition from (predominantly) grass- to shrub lands to forests occurs on decadal timescales and the simulated vegetation simply lags behind the warming/cooling signal and the rise/decrease in CO2. Additionally, the soil has a large inertia (due to the large amounts of energy required/released in the phase change of water), which also affects the vegetation via the soil water availability and finally there is the effect of the organic matter on the soil thermal/ hydrological properties, which leads to the ground behaving differently after the soil carbon loss due to a temporary warming. The question whether the hysteresis is realistic is not easy to answer as there are no observations for comparable warming/cooling scenarios. Here, we can only say that the hysteresis is a highly plausible behaviour and a robust feature in all of the 40 simulations that we conducted. Furthermore, the dynamics of the near surface permafrost are consistent with the findings of Eliseev (2014). Thus, we trust the tree cover hysteresis to be realistic to the extent to which we trust vegetation models in general.

- L.520-531: Discussion a bit unclear. This got me really confused. Does this NPP increase lead to more litter? Is this increased litter fraction the reason for the emissions? Otherwise hard to see how there can be an emission increase without increasing soil carbon emissions. The carbon must go somewhere, and come from somewhere... Or does the vegetation carbon increase?

Dr. Krinner is correct that the NPP dependency of the soil CO2 fluxes arises mainly from above and below ground litter, but the model also includes root exudates, fires and windbreak. Here we specified: "Another important driver of the soil $\mathrm{CO}_{2}$ fluxes is the carbon input into the soil - consisting of litter, root exudates but also damaged and burnt vegetation - which is largely dependent upon the net primary productivity (NPP)."

- L.660: At the end of this section, one wonders where all the sensitivity tests went. I have the impression that there could be made a better, clearer explicit use of

Printer-friendly version

Discussion paper
Interactive comment

C10 
the 40 members in terms of an assessment of the uncertainties.

We agree that the ensemble spread is not an ideal way to deal with the uncertainties and we actually went a lot further in the respective analysis. Unfortunately, we do not see a way to integrate this analysis in the present study without drastically increasing the amount of text, especially as this requires a much more detailed description, not only of the soil hydrology/energy schemes of the standard model but also of those of the model version described in Ekici (2014). Furthermore, many of the insights gained by analysing the ensemble (and additional sensitivity experiments) may also not be of great interest to the modelling community as they pertain to parametrizations/feedbacks that are very specific to JSBACH. Hence, we would prefer to show the ensemble spread, to demonstrate the large uncertainties even for a single land surface model with a prescribed atmospheric forcing, but without going into details with respect to their origin.

- L.671: Soil methane oxidation increase: could refer to Oh et al. 2020 and discuss similarities \& what is new.

In general, the oxidation rates in the methane module can be scaled for the wetand dry grid box fraction separately, in principal allowing to distinguish between high(dry)- and low(wet)-affinity methanotrophs. Here, we tuned the parameters with the help of atmospheric inversions (performed by the MPI for Biogeochemistry) for present day conditions, managing to capture a reasonable methane uptake by dry upland soils. However, the parameter values may not be ideal for future conditions if the temperature dependencies are substantially different between high- and low-affinity methanotrophs as indicated by Oh (2020). This could mean that the future net methane emissions simulated by JSBACH could be an overestimation, which we acknowledge in the conclusion section: "Thus, our results indicate that the soil methane fluxes in permafrost-affected regions do not constitute an important contributor to the climate-carbon feedback. Here, it should be noted that the net emissions could even be lower as a recent study

Printer-friendly version

Discussion paper 
has indicated that, especially in the future, the methane uptake in dry soils could be severely underestimated due to the omission of recently identified high-affinity methanotrophs (Oh, 2020)".

\section{Minor comments}

- L.4: "drive the model" might be better than "force the model"- Abstract, The text was changed accordingly.

- L.7: not only GHG decrease, but also reverse climate change is imposed on the land surface model

Here, we specified that the entire climate forcing is reversed to the initial levels: "The peaks are followed by a decrease in atmospheric GHGs that returns the concentrations to the levels at the beginning of the 21st century and reverses the imposed climate change".

- L.32: Arctic temperature increase twice the global mean - it might be more appropriate to compare the Arctic continental temperature change to the global continental average(but the numbers wouldn't be very different, probably)

Dr. Krinner is correct that for our study the terrestrial temperatures are more relevant. However, we did not change the manuscript because - as he correctly speculated - the numbers do not change fundamentally, while most studies discuss Arctic amplification without distinguishing between continental temperatures and sst.

- L.39: scenarios project a temperature increase between 3 and $8^{\circ} \mathrm{C}$ - it would be good to explicitly state that this uncertainty by 2100 comes to a very large degree from the diversity of the emission scenarios, not on the inter-model differences or internal variability

Printer-friendly version

Discussion paper 
We specified that the large spread is the result of the different GHG emissions assumed by the scenarios: "Depending on the assumed greenhouse gas (GHG) emissions, climate change scenarios project the Arctic temperatures to increase by between $3 \mathrm{~K}$ and $8 \mathrm{~K}$ until the end of the 21st century (Stocker, 2013)."

- L.43: timing of switch from sink to source highly uncertain - please provide some references here (maybe SROCC?)

In modelling studies, the timing of the sink-to-source switch appears to be highly model and scenario dependent, already providing a large degree of uncertainty. But while models predominantly place the switch from source to sink into the second half of the century, even for RCP8.5, a recent observation based study by Natali (2019) indicated that winter emissions could be substantially larger than previously thought and that the continental Arctic may already be a net source of atmospheric CO2. In the manuscript we have complemented the references provided to now include Schuur (2008); Schaefer (2011); Koven (2015); McGuire (2018); Parazoo (2018); Natali (2019).

- L.48: define what "near-surface permafrost" is.- replace "arctic" or "artic" (found several times) by "Arctic"- not sure "aerob" and "anaerob" are English words (should it read "(an)aerobic"?) -please check

Here we added that "near-surface" often refers to the top $3 \mathrm{~m}$ and all instances of "arctic" and "artic" were changed to "Arctic" while "(an)aerob" was replaced by "(an)aerobic".

- L.52: "permafrost-affectED soils"

The text was corrected.

- L.68: "the study's goal" -> "the goal of the study" (several such errors)

The manuscript was updated accordingly and, in general, we limit the use of the possessive to living things. 
- L.72: Given that this refers to political temperature targets, it might be useful to use more post-Paris 2015 references here

Here, we added Geden (2017); Ricke (2017); Rogelj (2015, 2018)

- L.203: "be including" -> "by including"

The text was corrected.

Interactive

comment

- L.227 "Permafrost-physics" -> "Permafrost physics" (there are many more examples of what I suspect is wrong hyphenization is this text)

Here, we corrected "Permafrost-physics" -> "Permafrost physics". In general, we double(-)checked and reduced our use of hyphens.

- L.335: "water tale" -> "water table"

The text was corrected.

- L.343: $\mathrm{CO} 2$ and $\mathrm{CH} 4$-> 2 and 4 are index, please.

Spelling was changed to subscript numbers throughout the manuscript.

- L.343: Please consider providing the equation even though many people know what a Q10 is

Here, we included the equation for the production of $\mathrm{CH} 4$ : "Partitioning of the anaerobic decomposition product $\left(R_{\text {anox }}\right)$ into $\mathrm{CO}_{2}$ and $\mathrm{CH}_{4}\left(\mathrm{P}_{\mathrm{CH}_{4}}\right)$ is temperature-dependent, with a baseline fraction of $\mathrm{CH}_{4}$ production $\mathrm{f}_{\mathrm{CH}_{4}}=0.35$ and a $Q 10$ factor for $f_{\mathrm{CH}_{4}}$ of $Q 10=1.8$ - with a reference temperature $\left(T_{\text {ref }}\right)$ of $295 K$.

$P_{\mathrm{CH}_{4}}=R_{\text {anox }} \cdot f_{\mathrm{CH}_{4}} \cdot Q_{10}^{\frac{T_{z}-T_{\text {ref }}}{10}} "$

- L.360: simulation period: CMIP6 historical period finishes in 2014, not 2015.

Please check.

Dr. Krinner is absolutely correct and the manuscript was changed accordingly. 
- L.382: "One key factor, determining..." - I think this is one example of a comma that shouldn't be there

We apologize for our (German) approach to punctuation and grammar in general, which we tried to correct throughout the manuscript.

- L.402, Eq. 25: "n_sim = n_c,soil *... * n_c,CH4 = 40" (add "= 40") - would make things clearer

The equation was updated accordingly.

- L.690: "Le Quéré", not "Quéré"

The reference was updated accordingly (Le Quéré, 2018).

- L.701: "not one model included an adequate representation..." - this might be a bit harsh. CCSM4, for example, probably isn't that far from being adequate, depending of course of what one thinks is adequate.

To the best of our knowledge, even CESM2 still had some problems with the high latitude carbon stocks in the CMIP6 simulations (Danabasoglu (2020); p. 26; reported a error in the spin-up phase). However - given the limitations of the CMIP6 version of the MPI-ESM - we should certainly not be the ones to judge what is adequate or not. Thus, we changed the respective formulation, leaving some room for a small number of models to have met the criteria: " ..., but hardly any of the models that participated in CMIP6 included an adequate representation of the soil physics in high latitudes, while simulating (interactive) vegetation dynamics as well as the carbon and nitrogen cycle".

\section{References}

Andresen, C. G., Lawrence, D. M., Wilson, C. J., McGuire, A. D., Koven, C., Schaefer, K., Jafarov, E., Peng, S., Chen, X., Gouttevin, I.,Burke, E., Chadburn, S., Ji, D., Chen, G., 
Hayes, D., and Zhang, W.: Soil moisture and hydrology projections of the permafrost region - amodel intercomparison, The Cryosphere, 14, 445-459, https://doi.org/10.5194/tc-14-4452020, https://doi.org/10.5194/tc-14-445-2020,2020.

Burke, E. J., Zhang, Y., and JKrinner, G.: Evaluating permafrost physics in the Coupled Model Intercomparison Project 6 (CMIP6) modelsand their sensitivity to climate change, The Cryosphere, 14, 3155-3174, https://doi.org/10.5194/tc-14-3155-2020, https://doi.org/10.5194/tc-14-3155-2020, 2020.

Danabasoglu, G., Lamarque, J.-F., Bacmeister, J., Bailey, D. A., DuVivier, A. K., Edwards, J., Emmons, L. K., Fasullo, J., Garcia, R., Gettel-man, A., Hannay, C., Holland, M. M., Large, W. G., Lauritzen, P. H., Lawrence, D. M., Lenaerts, J. T. M., Lindsay, K., Lipscomb, W. H.,Mills, M. J., Neale, R., Oleson, K. W., Otto-Bliesner, B., Phillips, A. S., Sacks, W., Tilmes, S., Kampenhout, L., Vertenstein, M., Bertini,A., Dennis, J., Deser, C., Fischer, C., Fox-Kemper, B., Kay, J. E., Kinnison, D., Kushner, P. J., Larson, V. E., Long, M. C., Mickelson, S.,Moore, J. K., Nienhouse, E., Polvani, L., Rasch, P. J., and Strand, W. G.: The Community Earth System Model Version 2 (CESM2), Journalof Advances in Modeling Earth Systems, 12, https://doi.org/10.1029/2019ms001916, https://doi.org/10.1029/2019ms001916, 2020.

Ekici, A., Beer, C., Hagemann, S., Boike, J., Langer, M., and Hauck, C.: Simulating highlatitude permafrost regions by the JSBACHterrestrial ecosystem model, Geosci. Model Dev., 7, 631-647, 2014.

Eliseev, A. V., Demchenko, P. F., Arzhanov, M. M., and Mokhov, I. I.: Transient hysteresis of near-surface permafrost response to exter-nal forcing, Climate Dynamics, 42, 1203-1215, https://doi.org/10.1007/s00382-013-1672-5, https://doi.org/10.1007/s00382013-1672-5,2014.

Geden, O. and Löschel, A.: Define limits for temperature overshoot targets, Nature Geoscience, 10, 881-882, https://doi.org/10.1038/s41561-017-0026-z, https://doi.org/10.1038/s41561017-0026-z, 2017.

Hagemann, S. and Stacke, T.: Impact of the soil hydrology scheme on simulated soil moisture memory, Climate Dynamics, 44, 1731-1750,https://doi.org/10.1007/s00382-014-22216, https://doi.org/10.1007/s00382-014-2221-6, 2015.

Hausfather, Z. and Peters, G. P.: Emissions - the 'business as usual' story is misleading, Nature, 577, 618-620,https://doi.org/10.1038/d41586-020-00177-3, https://doi.org/10.1038/d41586-020-00177-3, 2020.

Koven, C. D., Lawrence, D. M., and Riley, W. J.: Permafrost carbon-climate feed-

Discussion paper 
back is sensitive to deep soil carbon decomposability but notdeep soil nitrogen dynamics, Proceedings of the National Academy of Sciences, p. 201415123, https://doi.org/10.1073/pnas.1415123112,https://doi.org/10.1073/pnas.1415123112, 2015.

Le Quéré, C., Andrew, R. M., Friedlingstein, P., Sitch, S., Pongratz, J., Manning, A. C., Korsbakken, J. I., Peters, G. P., Canadell, J. G.,Jackson, R. B., Boden, T. A., Tans, P. P., Andrews, O. D., Arora, V. K., Bakker, D. C. E., Barbero, L., Becker, M., Betts, R. A., Bopp, L.,Chevallier, F., Chini, L. P., Ciais, P., Cosca, C. E., Cross, J., Currie, K., Gasser, T., Harris, I., Hauck, J., Haverd, V., Houghton, R. A., Hunt,C. W., Hurtt, G., Ilyina, T., Jain, A. K., Kato, E., Kautz, M., Keeling, R. F., Goldewijk, K. K., Körtzinger, A., Landschützer, P., Lefèvre,N., Lenton, A., Lienert, S., Lima, I., Lombardozzi, D., Metzl, N., Millero, F., Monteiro, P. M. S., Munro, D. R., Nabel, J. E. M. S., ichiroNakaoka, S., Nojiri, Y., Padin, X. A., Peregon, A., Pfeil, B., Pierrot, D., Poulter, B., Rehder, G., Reimer, J., Rödenbeck, C., Schwinger,J., Séférian, R., Skjelvan, I., Stocker, B. D., Tian, H., Tilbrook, B., Tubiello, F. N., van der Laan-Luijkx, I. T., van der Werf, G. R., vanHeuven, S., Viovy, N., Vuichard, N., Walker, A. P., Watson, A. J., Wiltshire, A. J., Zaehle, S., and Zhu, D.: Global Carbon Budget 2017,Earth System Science Data, 10, 405-448, https://doi.org/10.5194/essd-10-405-2018, https://doi.org/10.5194/essd-10-405-2018, 2018.

McGuire, A. D., Lawrence, D. M., Koven, C., Clein, J. S., Burke, E., Chen, G., Jafarov, E., MacDougall, A. H., Marchenko, S., Nicolsky,D., Peng, S., Rinke, A., Ciais, P., Gouttevin, I., Hayes, D. J., Ji, D., Krinner, G., Moore, J. C., Romanovsky, V., Schädel, C., Schaefer, K.,Schuur, E. A. G., and Zhuang, Q.: Dependence of the evolution of carbon dynamics in the northern permafrost region on the trajectoryof climate change, Proceedings of the National Academy of Sciences, 115, 3882-3887, https://doi.org/10.1073/pnas.1719903115, https://doi.org/10.1073/pnas.1719903115, 2018.

Natali, S. M., Watts, J. D., Rogers, B. M., Potter, S., Ludwig, S. M., Selbmann, A.-K., Sullivan, P. F., Abbott, B. W., Arndt, K. A., Birch, L.,Bjo İ́rkman, M. P., Bloom, A. A., Celis, G., Christensen, T. R., Christiansen, C. T., Commane, R., Cooper, E. J., Crill, P., Czimczik, C.,Davydov, S., Du, J., Egan, J. E., Elberling, B., Euskirchen, E. S., Friborg, T., Genet, H., Göckede, M., Goodrich, J. P., Grogan, P., Helbig,M., Jafarov, E. E., Jastrow, J. D., Kalhori, A. A. M., Kim, Y., Kimball, J. S., Kutzbach, L., Lara, M. J., Larsen, K. S., Lee, B.-Y., Liu, Z.,Loranty, M. M., Lund, M., Lupascu, M., Madani, N., Malhotra, A., Matamala, R., McFarland, J., McGuire, A. D., Michelsen, A., Minions,C., Oechel, W. C., Olefeldt, D., Parmentier, F.-J. W., Pirk, N., Poulter, B., Quinton, W., Rezanezhad, F., Risk, D., Sachs, T., Schaefer, K.,Schmidt, N. M., Schuur, E. A. G., Semenchuk, P. R., Shaver, G., Sonnentag, 
O., Starr, G., Treat, C. C., Waldrop, M. P., Wang, Y., Welker,J., Wille, C., Xu, X., Zhang, Z., Zhuang, Q., and Zona, D.: Large loss of CO2 in winter observed across the northern permafrost region,Nature Climate Change, 9, 852-857, https://doi.org/10.1038/s41558-0190592-8, https://doi.org/10.1038/s41558-019-0592-8, 2019.

Oh, Y., Zhuang, Q., Liu, L., Welp, L. R., Lau, M. C. Y., Onstott, T. C., Medvigy, D., Bruhwiler, L., Dlugokencky, E. J., Hugelius, G.,D'Imperio, L., and Elberling, B.: Reduced net methane emissions due to microbial methane oxidation in a warmer Arctic, Nature ClimateChange, 10, 317-321, https://doi.org/10.1038/s41558-020-0734-z, https://doi.org/10.1038/s41558020-0734-z, 2020.

Parazoo, N. C., Koven, C. D., Lawrence, D. M., Romanovsky, V., and Miller, C. E.: Detecting the permafrost carbon feedback: talik formationand increased cold-season respiration as precursors to sink-to-source transitions, The Cryosphere, 12, 123-144, https://doi.org/10.5194/tc12-123-2018, https://doi.org/10.5194/tc-12-123-2018, 2018.

Ricke, K. L., Millar, R. J., and MacMartin, D. G.: Constraints on global temperature target overshoot, Scientific Reports, 7,https://doi.org/10.1038/s41598-017-14503-9, https://doi.org/10.1038/s41598-017-14503-9, 2017.

Rogelj, J., Luderer, G., Pietzcker, R. C., Kriegler, E., Schaeffer, M., Krey, V., and Riahi, K.: Energy system transformations for limitingend-of-century warming to below $1.5{ }^{\circ} \mathrm{C}$, Nature Climate Change, 5, 519-527, https://doi.org/10.1038/nclimate2572, https://doi.org/10.1038/nclimate2572, 2015.

Rogelj, J., Popp, A., Calvin, K. V., Luderer, G., Emmerling, J., Gernaat, D., Fujimori, S., Strefler, J., Hasegawa, T., Marangoni, G., Krey,V., Kriegler, E., Riahi, K., van Vuuren, D. P., Doelman, J., Drouet, L., Edmonds, J., Fricko, O., Harmsen, M., Havlík, P., Humpenöder,F., Stehfest, E., and Tavoni, M.: Scenarios towards limiting global mean temperature increase below $1.5^{\circ} \mathrm{C}$, Nature Climate Change, 8,325-332, https://doi.org/10.1038/s41558-018-0091-3, https://doi.org/10.1038/s41558-018-0091-3, 2018.

Saunois, M., Stavert, A. R., Poulter, B., Bousquet, P., Canadell, J. G., Jackson, R. B., Raymond, P. A., Dlugokencky, E. J., Houweling, S.,Patra, P. K., Ciais, P., Arora, V. K., Bastviken, D., Bergamaschi, P., Blake, D. R., Brailsford, G., Bruhwiler, L., Carlson, K. M., Carrol,M., Castaldi, S., Chandra, N., Crevoisier, C., Crill, P. M., Covey, K., Curry, C. L., Etiope, G., Frankenberg, C., Gedney, N., Hegglin,M. I., Höglund-Isaksson, L., Hugelius, G., Ishizawa, M., Ito, A., Janssens-Maenhout, G., Jensen, K. M., Joos, F., Kleinen, T., Krummel,P. B., Langenfelds, R. L., Laruelle, G. G., Liu, L., Machida, T., Maksyutov, S., McDonald, K. C.,

Interactive comment
Printer-friendly version

Discussion paper 
McNorton, J., Miller, P. A., Melton,J. R., Morino, I., Müller, J., Murguia-Flores, F., Naik, V., Niwa, Y., Noce, S., O'Doherty, S., Parker, R. J., Peng, C., Peng, S., Peters, G. P.,Prigent, C., Prinn, R., Ramonet, M., Regnier, P., Riley, W. J., Rosentreter, J. A., Segers, A., Simpson, I. J., Shi, H., Smith, S. J., Steele, L. P.,Thornton, B. F., Tian, H., Tohjima, Y., Tubiello, F. N., Tsuruta, A., Viovy, N., Voulgarakis, A., Weber, T. S., van Weele, M., van der Werf,G. R., Weiss, R. F., Worthy, D., Wunch, D., Yin, Y., Yoshida, Y., Zhang, W., Zhang, Z., Zhao, Y., Zheng, B., Zhu, Q., Zhu, Q., and Zhuang,Q.: The Global Methane Budget 20002017, Earth System Science Data, 12, 1561-1623, https://doi.org/10.5194/essd-12-15612020,https://doi.org/10.5194/essd-12-1561-2020, 2020.

Schaefer, K., Zhang, T., Bruhwiler, L., and Barrett, A. P.: Amount and timing of permafrost carbon release in response to climate warming,Tellus $B, 63$, 165-180, https://doi.org/10.1111/j.1600-0889.2011.00527.x, https://doi.org/10.1111/j.16000889.2011.00527.x, 2011.

Schuur, E. A. G., Bockheim, J., Canadell, J. G., Euskirchen, E., Field, C. B., Goryachkin, S. V., Hagemann, S., Kuhry, P., Lafleur, P. M., Lee,H., Mazhitova, G., Nelson, F. E., Rinke, A., Romanovsky, V. E., Shiklomanov, N., Tarnocai, C., Venevsky, S., Vogel, J. G., and Zimov,S. A.: Vulnerability of Permafrost Carbon to Climate Change: Implications for the Global Carbon Cycle, BioScience, 58, 701-714,https://doi.org/10.1641/b580807, https://doi.org/10.1641/b580807, 2008.

Schuur, E. A. G., McGuire, A. D., Schädel, C., Grosse, G., Harden, J. W., Hayes, D. J., Hugelius, G., Koven, C. D., Kuhry, P., Lawrence,D. M., Natali, S. M., Olefeldt, D., Romanovsky, V. E., Schaefer, K., Turetsky, M. R., Treat, C. C., and Vonk, J. E.: Climate change and thepermafrost carbon feedback, Nature, 520, 171-179, https://doi.org/10.1038/nature14338, https://doi.org/10.1038/nature14338, 2015.

Stocker, T., Qin, D., Plattner, G.-K., Alexander, L., Allen, S., Bindoff, N., Bren, F.-M., Church, J., Cubasch, U., Emori, S., Forster, P.,Friedlingstein, P., Gillett, N., Gregory, J., Hartmann, D., Jansen, E., Kirtman, B., Knutti, R., Krishna Kumar, K., Lemke, P., Marotzke,J., Masson-Delmotte, V., Meehl, G., Mokhov, I., Piao, S., Ramaswamy, V., Randall, D., Rhein, M., Rojas, M., Sabine, C., Shindell,D., Talley, L., Vaughan, D., and Xie, S.-P.: Technical Summary, Book section, Cambridge, United Kingdom and New York, NY, USA,https://doi.org/10.1017/CBO9781107415324.005, www.climatechange2013.org, 2013.

Swenson, S. C., Lawrence, D. M., and Lee, H.: Improved simulation of the terrestrial hydrological cycle in permafrost regions by theCommunity Land Model, Journal of Ad-

Printer-friendly version

Discussion paper
Interactive

comment 
vances in Modeling Earth Systems, 4, n/a-n/a, https://doi.org/10.1029/2012ms000165, https://doi.org/10.1029/2012ms000165, 2012

Interactive comment on The Cryosphere Discuss., https://doi.org/10.5194/tc-2020-164, 2020.

Interactive

comment 